\title{
Bridging Taxonomic and Disciplinary Divides in Infectious Disease
}

\author{
Elizabeth T. Borer, ${ }^{1}$ Janis Antonovics, ${ }^{2}$ Linda L. Kinkel, ${ }^{3}$ Peter J. Hudson, ${ }^{4}$ Peter Daszak, ${ }^{5}$ \\ ${ }^{1}$ Department of Ecology, Evolution, and Behavior, University of Minnesota, St. Paul, MN 55108 \\ ${ }^{2}$ Department of Biology, University of Virginia, Charlottesville, VA 22904 \\ ${ }^{3}$ Department of Plant Pathology, University of Minnesota, St. Paul, MN 55108 \\ ${ }^{4}$ Center for Infectious Disease Dynamics, Penn State University, University Park, PA 16802 \\ ${ }^{5}$ EcoHealth Alliance, New York, NY 10001-2320 \\ ${ }^{6}$ Department of Plant Pathology, Kansas State University, Manhattan, KS 66506 \\ ${ }^{7}$ Department of Microbiology and Immunology, Cornell University, Ithaca, NY 14853 \\ ${ }^{8}$ Department of Plant Pathology, University of California, Davis, CA 95616-8751
}

Matthew J. Ferrari, ${ }^{4}$ Karen A. Garrett, ${ }^{6}$ Colin R. Parrish, ${ }^{7}$ Andrew F. Read, ${ }^{4}$ and David M. Rizzo ${ }^{8}$

\begin{abstract}
Pathogens traverse disciplinary and taxonomic boundaries, yet infectious disease research occurs in many separate disciplines including plant pathology, veterinary and human medicine, and ecological and evolutionary sciences. These disciplines have different traditions, goals, and terminology, creating gaps in communication. Bridging these disciplinary and taxonomic gaps promises novel insights and important synergistic advances in control of infectious disease. An approach integrated across the plant-animal divide would advance our understanding of disease by quantifying critical processes including transmission, community interactions, pathogen evolution, and complexity at multiple spatial and temporal scales. These advances require more substantial investment in basic disease research.
\end{abstract}

Keywords: epidemics, within-host dynamics, prediction, prevention, cross-species transmission, invasive species

\section{INTRODUCTION}

Pathogens do not respect disciplinary or taxonomic boundaries. However, infectious disease research has been and still is the province of many separate disciplines including veterinary medicine, plant pathology, and human medicine, where these fields are defined by the host organism being studied rather than by the concepts that cut across

Published online: November 16, 2011

Correspondence to: Elizabeth T. Borer, e-mail: borer@umn.edu taxonomic boundaries. In the past decade, infectious disease research also has captured the full attention of the ecological and evolutionary sciences. These disciplines each have different traditions, different goals, and often quite different terminology, creating significant gaps in communication. For example, the word 'virulence' is defined differently by plant pathologists, evolutionary biologists, and medical doctors; similarly, the term 'drift' evokes quite different processes for a population geneticist and a researcher of influenza. Terminological inconsistency is only a symptom of larger divides, and it is clear that bridging these disciplinary and taxonomic gaps to allow true interdisciplinary 
research efforts will lead to novel insights, important synergistic interactions across fields, and advanced understanding and ability to control infectious disease.

A truly interdisciplinary approach will hasten understanding, leading to novel insights that will benefit all of the disciplines involved. In particular, an approach which is agnostic to the taxonomy of the host, focusing on the fundamental ecological and evolutionary processes inherent to a pathogenic lifestyle (e.g., transmission, host immune or other defenses, virulence, or species interactions), promises rapid conceptual and technical advances. Further, by employing a comparative approach that is inclusive of microorganisms, plants, wild and domestic animals, and humans, we will deepen our understanding of disease for all of these fields. The exchange of specific techniques and quantitative tools also will open up approaches for dealing with complexity at multiple spatial and temporal scales. Infectious disease in humans and in plant and animal agriculture (or in domesticated companion animals) is often the direct consequence of interactions with non-agricultural populations of the same hosts (Cleaveland et al. 2001; Taylor et al. 2001; Anderson et al. 2004; Parrish et al. 2008). Achieving an understanding of transmission and evolutionary dynamics in both wild and domesticated hosts will offer novel solutions to emerging infectious disease challenges. For example, this type of approach has proven successful in advancing our understanding of two recent emerging diseases, white nose syndrome in bats and chytridiomycosis in frogs (Berger et al. 1998; Blehert et al. 2009). In both cases, long-term expertise in the pathology and ecology of fungal pathogens of plants allowed the efficient identification of these extremely significant fungal pathogens of wildlife. The study of plant sexually transmitted diseases also has stimulated increased understanding of sexually transmitted diseases in animals and humans (Lockhart et al. 1996), including the role played by basal immune system functioning (Nunn et al. 2000).

Fundamental epidemiological problems can be addressed and illuminated by gathering data across many systems. For example, a general understanding of the accelerating nature of epidemic spread has arisen from a multi-species approach (Mundt et al. 2009). Similarly, wellunderstood principles in one area can provide critical insights in another. For example, genetic variation in host resistance is commonly considered in plant pathology, but is less often explicitly considered in studies of animal diseases. While it is hard to judge issues from hindsight, we posit that if the medical research community, when confronted with the early stages of the AIDS epidemic, had been as aware of genetic variation in host resistance to pathogens as the average plant pathologist, the understanding of the pathology of HIV and the development of anti-viral therapies based on this knowledge would have advanced far more rapidly (Pettipher and Cardon 2002; Lederman et al. 2006). Communication across this divide could have changed history.

The science of infectious disease is poised for enormous advances if scientists can communicate, collaborate, and synthesize across organismal and conceptual divides. Here we provide examples of concepts and techniques spanning disciplinary divides, where combining the common approaches taken to understand plant, animal, and human disease could generate strong synergy, and we argue that such translational science requires active investment in truly interdisciplinary programs by funding agencies.

\section{Pathogen Transmission and Epidemics}

The principles underlying pathogen dispersal among hosts and epidemics are shared across animal and plant hosts (Mundt et al. 2009), and control strategies for both plant and animal pathogens can be mutually informative. For example, Asiatic citrus canker, an infection caused by the bacterium Xanthomonas citri subsp. citri, produces bacterium-leaking lesions on leaves and fruit which are harmless to humans but are unsightly and dramatically reduce the economic value of infected citrus (Gottwald et al. 2002a). By providing information on critical parameters to stem an epidemic, the mathematical models of the spread of foot and mouth disease (FMDV) that have been developed to inform the control of outbreaks in European livestock (e.g., Keeling et al. 2003; Haydon et al. 2004) could have provided information to guide control strategies for plant pathogen outbreaks like citrus canker in Florida (Schubert et al. 2001; Gottwald et al. 2002b). Further, the lessons learned from the coordinated response between individual producers, industry, and national agencies to implement policy and response to FMDV outbreaks (Haydon et al. 2004) are key components for evaluation of practical control strategies for citrus canker and other large-scale agricultural pathogens. For example, FMDV data now exist on the social, biological, and economic effects of ring culling, culling of apparently uninfected herds, and bans on livestock movement, all of which could be used for developing more effective strategies to control the transmission of other plant and animal diseases.

In addition, predicting the scaling of epidemic processes from local to continental levels remains a challenge 
because of a paucity of examples within any individual host taxa (i.e., humans, livestock, wildlife, crops). The handful of well-documented continental scale outbreaks (e.g., influenza in humans (Viboud et al. 2006), rabies in raccoons (Smith et al. 2002), soybean rust (Isard et al. 2005), and sudden oak death (Meentemeyer et al. 2008)) have revealed that locally homogeneous transmission dynamics give way to strongly heterogeneous transmission patterns at the continental scale that are dominated by a combination of local environmental suitability (Isard et al. 2005; Meentemeyer et al. 2008), host movement patterns (Smith et al. 2002; Viboud et al. 2006), or atmospheric currents (Isard et al. 2005). Novel methods combining transmission models, geographic information system (GIS), and remote sensing to quantify risk of outbreaks and predict disease spread in plant pathogens (Meentemeyer et al. 2004; Mumma et al. 2009) can be adapted to address other threats at the national level, and experimental work on pathogens, such as sudden oak death or wheat rusts (Mundt et al. 2009; Meentemeyer et al. 2011) promises significant advances in predicting regional- or nationalscale infectious disease spread. Given the limited number of continental or global scale epidemics that can be studied, understanding the role of local and regional controls on transmission dynamics would clearly benefit from a comparative approach that is agnostic to host taxonomy. Containing any emerging infectious disease, newly introduced or evolved pathogen, bioterror or agroterror agent will benefit from recognition of the similarities among pathogens infecting animal and plant hosts and rapid, efficient communication among researchers in different disciplines to effectively translate such models into recommendations that can aid decision makers.

\section{Within-Host Dynamics and Among-Host Heterogeneity}

A major challenge in the study of infectious diseases is to explain the large variation in the response of hosts to infection, from those that exhibit no disease symptoms to those that die rapidly or result in exceptionally high levels of transmission (super spreaders). These variable responses have important repercussions for identifying and predicting disease spread and consequently for developing and implementing intervention methods. Though behavioral, physiological, and genetic determinants of variation in susceptibility have been well-studied, recent work in both medicine and agriculture suggests that variation in host health and resistance to novel microbes may also be caused by community level ecological interactions among different microbes. The vast majority of microbes are not pathogenic, and thus pathogen infection in many cases is akin to the invasion of a novel microbe into an existing community within a host. Current work in both plant and animal hosts is revealing that colonies of microbes can produce antimicrobial compounds that protect against infection or colonization by unrelated pathogens (Conn et al. 2008; Harris et al. 2009; Verma et al. 2009). Bacteriotherapy is a new and extremely promising manipulation of microbes in humans to control disease (Khoruts et al. 2010). Through closer communication, these parallel inquiries and novel findings in both plants and animals have great potential to develop powerful new "biocontrol" tools for both humans and agriculture, especially given the ubiquitous problem of rapid evolution of resistance to anti-microbial agents.

Genomic advances also are opening the window onto polymicrobial infections (e.g., AIDS and TB co-infections in humans, fungal co-infections within crops, phage diversity within bacterial infections), and the Human Microbiome Project is expanding our knowledge of the vast microbial diversity and its critical functions for human health (Nelson et al. 2010). The field of community ecology is able to bridge the plant-animal divide to explain how the diversity of species and their interactions in communities of both micro- and macro-organisms affects the stability and resilience of individual species and the community as a whole. The specific application of community ecology principles to pathogen and parasite communities promises substantial conceptual and technical synergy in understanding the heterogeneity in responses to infection among hosts as well as treatment of microbial perturbations in plant and animal hosts, including humans.

\section{Prediction and Prevention}

Many agricultural populations are made up of genetically identical or very closely related individuals, posing unique challenges for disease control, but also providing a fertile testing ground for predicting pathogen evolution within hosts and across landscapes (McDonald 2010). Plant crop systems have provided clear tests of the basic prediction that genetic homogeneity of hosts should favor more virulent pathogens (Clay and Kover 1996; Zhu et al. 2000). The development of genetically engineered crops for food and biofuels or cloned animals will almost certainly involve important tradeoffs among productivity, disease tolerance, 
and disease resistance that will not be fully understood until production is at a large scale. A comparative approach, drawing from research on such tradeoffs in both plants and animals, will provide us with advanced warning of such problems. In addition, careful analysis will provide a better understanding of the potential threat of transfer of transgenes into wild populations, but that will require an appreciation of the effects of net trait fitness in both agricultural and wild settings (e.g., Sasu et al. 2009, 2010). Further, in plants, movement of strains or prediction of which endemic strains will reach outbreak levels can be improved by genetic tracing, now that sequencing is becoming much less expensive. This type of tracking is done extensively for human pathogens like influenza and anthrax (Fricke et al. 2009) and has been performed intensively for a small number of plant pathogens (e.g., rusts, Chen et al. 2010). Prediction of evolutionary trajectories and outbreaks of human and crop pathogens are therefore critical to informing broad-scale pathogen control programs in animals and humans, and breeding programs in plants. Genomic approaches promise to revolutionize our ability to predict and prevent biological threats to both humans and agriculture (Fricke et al. 2009).

\section{Cross-Species Transmission and Emergence}

Many pathogens cross the boundaries between wild or nonagricultural hosts and humans or agricultural species (Cleaveland et al. 2001; Taylor et al. 2001; Anderson et al. 2004; Parrish et al. 2008), and these interspecific transmission events are often the source of new emerging infectious diseases (Lloyd-Smith et al. 2009). Diseases such as Lyme disease, bartonellosis, and West Nile Virus have highlighted the roles of wild animal host species as reservoirs of infection that increase human health risk (Ostfeld and Holt 2004; Ezenwa et al. 2006; Telfer et al. 2007). We are only beginning to examine pathogens that can replicate and cause disease in both animal and plant hosts (Schikora et al. 2008; Saleh et al. 2010). Viral, fungal, and bacterial plant pathogens, such as barley yellow dwarf virus, Macrophomina phaseolina (charcoal rot), or X. citri subsp. citri (Asiatic citrus canker) can serve as excellent, experimentally tractable, model systems for understanding the underlying drivers and outcomes of cross-species transmission for both plants and animals (Gottwald et al. 2002a; Power and Mitchell 2004; Malmstrom et al. 2005; Borer et al. 2009; Borer et al. 2010; Saleh et al. 2010). Disease risk across taxonomic boundaries requires a greater understanding of the interspecific force of infection or host barriers to infection, as well as the barriers that prevent outbreaks from developing, that likely result from complex pathways of ecological change. Using this knowledge for infection control or prevention will require understanding the population and community dynamics of the non-human and non-agricultural host species.

The emergence and establishment of significant novel pathogens is a rare and poorly understood phenomenon. Predicting the risk of emergence is fundamentally limited by a lack of well-documented case studies and of good experimental data. As such, basic questions about the role of encounter rates versus genetic variance (in either the host or pathogen) in determining the likelihood of emergence remain open. Comparative analyses across taxa have provided the best picture of the limits to pathogen host range and interspecific variation in within-host parasite diversity (Power and Flecker 2008; Lloyd-Smith et al. 2009) and may provide the best steps toward a general theory of pathogen emergence. The factors that lead to emergence of novel diseases and epidemics span disciplines including biomedical, earth systems, epidemiology, ecology, environmental sciences, and evolutionary genomics, to name a few. Communication and collaboration by researchers who study plant, animal, and human pathogens, as well as between basic researchers and applied practitioners are critical for advancing our ability to predict pathogen emergence and establishment in the coming years.

\section{Invasive Species}

Wildlife animal and plant trade, relocation, and invasion all can lead to movement of pathogens, threatening biological diversity and human, domesticated animal, and crop health (Daszak et al. 2000; Waage and Mumford 2008), and plant, animal, and microbial invasions into agriculture cause enormous economic losses (Schumann and D'Arcy 2010). Invasions may be driven by pathogen loss; alternatively, invasive species may themselves become pathogen reservoirs (Allison 1982; Calvo-Ugarteburu and McQuaid 1998; Borer et al. 2007). Moreover, the invasion of novel arthropod vectors is a problem common across the taxonomic spectrum (e.g., Juliano and Lounibos 2005; Morse and Hoddle 2006). Biosecurity threats for both animals and plants are commonly treated on a case-by-case basis, sometimes at extreme expense. A critical current and future challenge is to place these threats and events into a broader, quantitative risk-assessment context that includes established pests and diseases and the natural ecosystems in which they occur (Waage and Mumford 2008). 


\section{Policy Issues}

Translational science drawing on the opportunities outlined here will require investment in both basic and applied disease research. While the synergies available from examining disease across the plant-animal divide are recognized by some scientists and practitioners (Olsen et al. 2011), the funding agencies lag far behind. With few exceptions, the funds devoted to infectious disease research at the United States Department of Agriculture (USDA) and the US National Institutes of Health $(\mathrm{NIH})$ are designated for specific problems associated with specific diseases. While research in closely defined areas is appropriate and should continue, it is remarkable that only a miniscule fraction of funding is available for basic disease research. For example, the Division of Allergy and Infectious disease at NIH receives a total annual budget of nearly $\$ 5,000$ million (excluding programs dealing explicitly with AIDS), whereas the only program supporting research on infectious disease that is independent of the taxonomy of the study organism is entitled "Ecology of Infectious Disease." This program is jointly funded by NIH and NSF in the region of only $\$ 15$ million per year, to which $\mathrm{NIH}$ makes a contribution of about a third (less than $0.1 \%$ of the Allergy and Infectious Disease division funding at $\mathrm{NIH}$ ). To date, there has been no contribution to this program from USDA, which itself does not support general research on infectious disease, even though approximately $\$ 70$ million of the USDA budget is dedicated annually to research on specific plant diseases. It is critical that all agencies, especially NIH and USDA, strongly support basic research in ecology and evolution of infectious diseases, particularly recognizing the great potential insights promised by cross-disciplinary and cross-taxonomic research initiatives. Active calls for proposals that bridge the plantanimal-human divides and which integrate evolutionary and ecological theory into understanding the fundamental processes that are shared among infectious diseases would greatly stimulate important translational science. Such programs also would stimulate interactions among scientists who are constrained by the organism-specific, or disease-specific funding structures and programs.

\section{SUMMARY}

Ecological, epidemiological, and evolutionary principles guide our understanding of disease emergence, epidemic spread, host-pathogen co-evolution, and the cascading repercussions of disease on the dynamics of all host-pathogen systems, whether microbial, plant, or animal, including human-based. Such understanding has already directly informed the practical needs of agriculture and medical sciences, but much more could be done to promote this synergism. Agricultural and natural systems provide experimental opportunities unavailable to human medicine. Plants in particular have illuminated our knowledge of mobile genetic elements, the role of gene-silencing in resistance and its application to genetic engineering, and conceptual aspects of demography and micro-evolution. Plants provide tractable model systems in which large experiments in disease dynamics at multiple spatial scales are possible (e.g., Borer et al. 2010). While the disjunction between the needs of pure and applied sciences may seem large, the success of genomic and phylogenetic approaches in explaining infectious disease dynamics and evolution in all kingdoms of life illustrates the tremendous potential synergism that could arise from close communication among ecologists, evolutionary biologists, applied scientists, plant pathologists, and veterinary and medical practitioners. We urge development of new programs and increased funding for existing programs that facilitate integration of these parallel lines of questioning to overcome language, taxonomic, and disciplinary barriers. Such funding will refocus these fields, opening the door to increased synthesis and providing important synergistic advances in understanding, analyzing, and controlling infectious disease.

\section{ACKNOWLEDGMENTS}

Many thanks to all of the participants in the NSF/NIH workshop, Frontiers of Research in Infectious Disease Ecology (April 2010) for ideas and stimulating discussion. We also thank the NSF/NIH Ecology of Infectious Disease program for supporting this workshop. Borer also received support from the University of Minnesota and NSF Ecology and Evolution of Infectious Disease grant DEB-1015805.

\section{Open Access}

This article is distributed under the terms of the Creative Commons Attribution Noncommercial License which permits any noncommercial use, distribution, and reproduction in any medium, provided the original author(s) and source are credited. 


\section{REFERENCES}

Allison AC (1982) Coevolution between hosts and infectious disease agents, and its effects on virulence. In: Population Biology of Infectious Disease, Anderson RM, May RM (editors), Berlin/ New York: Springer-Verlag, pp 245-267

Anderson PK, Cunningham AA, Patel NG, Morales FJ, Epstein PR, Daszak P (2004) Emerging infectious diseases of plants: pathogen pollution, climate change and agrotechnology drivers. Trends in Ecology \& Evolution 19:535-544

Berger L, Speare R, Daszak P, Green DE, Cunningham AA, Goggin CL, Slocombe R, Ragan MA, Hyatt AD, McDonald KR, Hines HB, Lips KR, Marantelli G, Parkes H (1998) Chytridiomycosis causes amphibian mortality associated with population declines in the rain forests of Australia and Central America. Proceedings of the National Academy Sciences of the United States of America 95:9031-9036

Blehert DS, Hicks AC, Behr M, Meteyer CU, Berlowski-Zier BM, Buckles EL, Coleman JTH, Darling SR, Gargas A, Niver R, Okoniewski JC, Rudd RJ, Stone WB (2009) Bat white-nose syndrome: an emerging fungal pathogen? Science 323:227

Borer ET, Hosseini PR, Seabloom EW, Dobson AP (2007) Pathogen-induced reversal of native dominance in a grassland community. Proceedings of the National Academy Sciences of the United States of America 104:5473-5478

Borer ET, Mitchell CE, Power AG, Seabloom EW (2009) Consumers indirectly increase infection risk in grassland food webs. Proceedings of the National Academy Sciences of the United States of America 106:503-506

Borer ET, Seabloom EW, Mitchell CE, Power AG (2010) Local context drives infection of grasses by vector-borne generalist viruses. Ecology Letters 13:810-818

Calvo-Ugarteburu G, McQuaid CD (1998) Parasitism and invasive species: effects of digenetic trematodes on mussels. Marine Ecology Progress Series 169:149-163

Chen XM, Penman L, Wan AM, Cheng P (2010) Virulence races of Puccinia striiformis f. sp tritici in 2006 and 2007 and development of wheat stripe rust and distributions, dynamics, and evolutionary relationships of races from 2000 to 2007 in the United States. Canadian Journal of Plant Pathology 32:315-333

Clay K, Kover PX (1996) The Red Queen Hypothesis and plant/ pathogen interactions. Annual review of Phytopathology 34:29-50

Cleaveland S, Laurenson MK, Taylor LH (2001) Diseases of humans and their domestic mammals: pathogen characteristics, host range and the risk of emergence. Philosophical Transactions of the Royal Society of London Series B: Biological Sciences 356:991-999

Conn VM, Walker AR, Franco CMM (2008) Endophytic actinobacteria induce defense pathways in Arabidopsis thaliana. Molecular Plant-Microbe Interactions 21:208-218

Daszak P, Cunningham AA, Hyatt AD (2000) Emerging infectious diseases of wildlife - threats to biodiversity and human health. Science 287:443-449

Ezenwa VO, Godsey MS, King RJ, Guptill SC (2006) Avian diversity and West Nile virus: testing associations between biodiversity and infectious disease risk. Proceedings of the Royal Society of London B 273:109-117

Fricke WF, Rasko DA, Ravel J (2009) The role of genomics in the identification, prediction, and prevention of biological threats. PLoS Biology 7:e1000217
Gottwald TR, Graham JH, Schubert TS (2002a) Citrus canker: the pathogen and its impact. Plant Health Progress, Online.

Gottwald TR, Sun X, Riley T, Graham JH, Ferrandino F, Taylor EL (2002) Geo-referenced spatiotemporal analysis of the urban citrus canker epidemic in Florida. Phytopathology 92:361-377

Harris RN, Brucker RM, Walke JB, Becker MH, Schwantes CR, Flaherty DC, Lam BA, Woodhams DC, Briggs CJ, Vredenburg VT, Minbiole KPC (2009) Skin microbes on frogs prevent morbidity and mortality caused by a lethal skin fungus. ISME Journal 3:818-824

Haydon DT, Kao RR, Kitching RP (2004) The UK foot-andmouth disease outbreak-the aftermath. Nature Reviews Microbiology 2:675-681

Isard SA, Gage SH, Comtois P, Russo JM (2005) Principles of the atmospheric pathway for invasive species applied to soybean rust. BioScience 55:851-861

Juliano SA, Lounibos LP (2005) Ecology of invasive mosquitoes: effects on resident species and on human health. Ecological Letters 8:558-574

Keeling MJ, Woolhouse MEJ, May RM, Davies G, Grenfell BT (2003) Modelling vaccination strategies against foot-and-mouth disease. Nature 421:136-142

Khoruts A, Dicksved J, Jansson JK, Sadowsky MJ (2010) Changes in the composition of the human fecal microbiome after bacteriotherapy for recurrent Clostridium difficile-associated diarrhea. Journal of Clinical Gastroenterology 44:354-360

Lederman MM, Penn-Nicholson A, Cho M, Mosier D (2006) Biology of CCR5 and its role in HIV infection and treatment. JAMA: The Journal of the American Medical Association 296: 815-826

Lloyd-Smith JO, George D, Pepin KM, Pitzer VE, Pulliam JRC, Dobson AP, Hudson PJ, Grenfell BT (2009) Epidemic dynamics at the human-animal interface. Science 326:1362-1367

Lockhart AB, Thrall PH, Antonovics J (1996) Sexually transmitted diseases in animals: ecological and evolutionary implications. Biological Review 71:415-471

Malmstrom CM, Hughes CC, Newton LA, Stoner CJ (2005) Virus infection in remnant native bunchgrasses from invaded California grasslands. New Phytologist 168:217-230

McDonald B (2010) How can we achieve durable disease resistance in agricultural ecosystems? New Phytologist 185:3-5

Meentemeyer R, Cunniffe NJ, Cook AR, Filipe JAN, Hunter RD, Rizzo DM, Gilligan CA (2011) Epidemiological modeling of invasion in heterogeneous landscapes: spread of sudden oak death in California (1990-2030). Ecosphere, 2, article 17.

Meentemeyer R, Rizzo D, Mark W, Lotz E (2004) Mapping the risk of establishment and spread of sudden oak death in California. Forest Ecology and Management 200:195-214

Meentemeyer RK, Anacker BL, Mark W, Rizzo DM (2008) Early detection of emerging forest disease using dispersal estimation and ecological niche modeling. Ecological Applications 18: 377-390

Morse JG, Hoddle MS (2006) Invasion biology of thrips. Annual Review of Entomology 51:67-89

Mumma EP, Schneider RW, Robertson CL (2009) Association of specific variables with severity of Asian soybean rust as assessed by GIS analysis at the field level. Phytopathology 99:S91

Mundt CC, Sackett KE, Wallace LD, Cowger C, Dudley JP (2009) Long-distance dispersal and accelerating waves of disease: empirical relationships. American Naturalist 173:456-466 
Nelson KE, Weinstock GM, Highlander SK, Worley KC, Creasy HH, Wortman JR, Rusch DB, Mitreva M, Sodergren E, Chinwalla AT, Feldgarden M, Gevers D, Haas BJ, Madupu R, Ward DV, Birren B, Gibbs RA, Methe B, Petrosino JF, Strausberg RL, Sutton GG, White OR, Wilson RK, Durkin S, Gujja S, Howarth C, Kodira CD, Kyrpides N, Madupu R, Mehta T, Mitreva M, Muzny DM, Pearson M, Pepin K, Pati A, Qin X, Yandava C, Zeng QD, Zhang L, Berlin AM, Chen L, Hepburn TA, Johnson J, McCorrison J, Miller J, Minx P, Nusbaum C, Russ C, Sutton GG, Sykes SM, Tomlinson CM, Young S, Warren WC, Badger J, Crabtree J, Madupu R, Markowitz VM, Orvis J, Rusch DB, Sutton GG, Cree A, Ferriera S, Gillis M, Hemphill LD, Joshi V, Kovar C, Wetterstrand KA, Abouellleil A, Wollam AM, Buhay CJ, Ding Y, Dugan S, Fulton LL, Fulton RS, Holder M, Hostetler J, Sutton GG, Allen-Vercoe E, Badger J, Clifton SW, Earl AM, Farmer CN, Giglio MG, Liolios K, Surette MG, Sutton GG, Torralba M, Xu Q, Pohl C, Durkin S, Sutton GG, WilczekBoney K, Zhu DH, Jumpstart HM (2010) A catalog of reference genomes from the human microbiome. Science 328:994-999

Nunn CL, Gittleman JL, Antonovics J (2000) Promiscuity and the primate immune system. Science 290:1168-1170

Olsen L, Choffner ER, Relman DA, Pray L (2011) Fungal diseases: an emerging threat to human, animal, and plant health. In: Forum on Microbial Threats, Board on Global Health, Institute of Medicine of the National Academies Washington, DC, p 455

Ostfeld RS, Holt RD (2004) Are predators good for your health? Evaluating evidence for top-down regulation of zoonotic disease reservoirs Frontiers in Ecology and the Environment 2:13-20

Parrish CR, Holmes EC, Morens DM, Park E-C, Burke DS, Calisher CH, Laughlin CA, Saif LJ, Daszak P (2008) Cross-species virus transmission and the emergence of new epidemic diseases. Microbiology and Molecular Biology Reviews 72:457-470

Pettipher R, Cardon LR (2002) The application of genetics to the discovery of better medicines. Pharmacogenomics 3:257-263

Power A, Flecker A (2008) The role of vector diversity in disease dynamics. In: Infectious disease ecology: effects of ecosystems on disease and of disease on ecosystems, Ostfeld R, Keesing F, Eviner V (editors), Princeton, NJ: Princeton University Press, pp 30-47

Power AG, Mitchell CE (2004) Pathogen spillover in disease epidemics. American Naturalist 164:S79-S89

Saleh AA, Ahmed HU, Todd TC, Travers SE, Zeller KA, Leslie JF, Garrett KA (2010) Relatedness of Macrophomina phaseolina isolates from tallgrass prairie, maize, soybean and sorghum. Molecular Ecology 19:79-91

Sasu MA, Ferrari MJ, Du DL, Winsor JA, Stephenson AG (2009) Indirect costs of a nontarget pathogen mitigate the direct ben- efits of a virus-resistant transgene in wild Cucurbita. Proceedings of the National Academy Sciences of the United States of America 106:19067-19071

Sasu M, Ferrari MJ, Stephenson AG (2010) Interrelationships among a virus-resistance transgene, herbivory, and a bacterial disease in a wild cucurbita. International Journal of Plant Sciences 171:1048-1058

Schikora A, Carreri A, Charpentier E, Hirt H (2008) The dark side of the salad: Salmonella typhimurium overcomes the innate immune response of Arabidopsis thaliana and shows an endopathogenic lifestyle. PLoS ONE 3:e2279

Schubert TS, Rizvi SA, Sun XA, Gottwald TR, Graham JH, Dixon WN (2001) Meeting the challenge of eradicating citrus canker in Florida-Again. Plant Disease 85:340-356

Schumann GL, D’Arcy CJ (2010) Essential Plant Pathology, St. Paul, MN: APS Press

Smith DL, Lucey B, Waller LA, Childs JE, Real LA (2002) Predicting the spatial dynamics of rabies epidemics on heterogeneous landscapes. Proceedings of the National Academy Sciences of the United States of America 99:3668-3672

Taylor LH, Latham SM, Woolhouse MEJ (2001) Risk factors for human disease emergence. Philosophical Transactions of the Royal Society of London Series B-Biological Sciences 356:983-989

Telfer S, Begon M, Bennett M, Bown KJ, Burthe S, Lambin X, Telford G, Birtles R (2007) Contrasting dynamics of Bartonella spp. in cyclic field vole populations: the impact of vector and host dynamics. Parasitology 134:413-425

Verma VC, Gond SK, Kumar A, Mishra A, Kharwar RN, Gange AC (2009) Endophytic actinomycetes from Azadirachta indica A. Juss.: isolation, diversity, and anti-microbial activity. Microbial Ecology 57:749-756

Viboud C, Bjornstad ON, Smith DL, Simonsen L, Miller MA, Grenfell BT (2006) Synchrony, waves, and spatial hierarchies in the spread of influenza. Science 312:447-451

Waage JK, Mumford JD (2008) Agricultural biosecurity. Philosophical Transactions of the Royal Society B: Biological Sciences 363:863-876

Zhu YY, Chen HR, Fan JH, Wang YY, Li Y, Chen JB, Fan JX, Yang SS, Hu LP, Leung H, Mew TW, Teng PS, Wang ZH, Mundt CC (2000) Genetic diversity and disease control in rice. Nature 406:718-722 